\title{
Avoiding Gadget Addiction in Children by Helping Children to Develop Talents and Interests
}

\author{
Vidya Dwi Amalia Zati ${ }^{1 *}$, Faisal $^{1}$, Srinahyanti ${ }^{1}$ and Rafael Lisinus Ginting ${ }^{1}$ \\ \{*vdaz_1312@yahoo.com \} \\ ${ }^{1}$ Faculty of Education, Universitas Negeri Medan, Indonesia
}

\begin{abstract}
Technology plays important role in people's lives. Since gadgets are popular in children, it brings both positive and negative impacts for children. The serious negative impact is causing gadget addiction in children. This problem needs to be solved soon in order to avoid further negative impacts in the future, like health issues, social isolation, lack of interest in studying and negative impact on character. One of the effective ways to avoid gadget addiction is by helping children to develop their talents and interests to prevent children from gadgets overuse. Both parents and teachers have essential role in solving this problem. Both of them should provide positive activities that lead children to discover and develop their talents and interests
\end{abstract}

Keywords: Gadget addiction, talent, interest

\section{Introduction}

Nowadays technology plays important role in people's lives. Technology leads the way to amazing advancement in numerous fields, it is helpful in education, research and almost in every aspect of life. As the gadgets are increasing and becoming so popular day by day, it brings many positive and negative impacts too. It makes people easier in doing activities and it is also leading to the technology addiction among people, both adult and children. Its addictive effects have become a growing concern, many adults and children wastetheir time on games and applications.

According to many researches, children spend average of time on gadgets, like smartphone, tablet, computer, TV, Xbox, PlayStation and so on. They spend their time to playing games, watching movies, chatting with friends, listening songs and browsing in internet. Children as young as 2 years even use gadgets with great ease. They learn easily by imitating their parent's behavior. Tons of parents use gadgets and sometimes it makes them ignore their children in front of them because they are too busy to use gadgets, whether for working or just for having fun. For some busy parents, they give gadgets to children to make them calm down and behave, so parents can do another activity without being interrupted by their children. Without them realizing, this behavior can make children become addicted to gadgets. Some children will be hysteric and restless when they cannot get it from parents.

Gadget addiction in children also become a serious problem that occur in society nowadays. Many children tend to play gadgets and spend many hours just to play games and application rather than socialize with others. It makes them being anti-social, because they find their happiness in virtual world nor in real world. It is such a modern era phenomenon where children prefer use gadgets as their playground instead of playing outside with friends. 
Furthermore, children also spend most of time using gadgets and don't pay attention to their health.

Addiction is a serious problem. It needs to be solved soon in order to decrease further serious effects in the future. Hence, there are various adverse effects of gadget addiction. People also need to know the importance of prevention that is carried out on gadget addiction, so it is very important to know the problem solving in helping children not to become addicted to gadgets.

\section{Methodology}

\subsection{The Negative Impacts of Gadgets for Children}

There are many negative impacts that arise from excessive use of gadgets, such as health issues, social isolation, lack of interest in studying, negative impact on character and so on.

\section{a. Health Issue}

Health issue become one of serious effect caused by gadgets. Children spend most of time using gadgets and don't pay attention to their health, the screen brightness, screen distance and duration of usage actually will be affected to vision and health. Spending too much time in gadgets can cause eyes irritation and hearing problem, lay down at home and worse of all, apart from lacking in physical activity. Gadgets also make children become aggressive. Some children will be more emotional when they cannot find gadgets around them and get paranoid when they do not have gadgets with them.

\section{b. Social Isolation}

Social isolation is related to the lack of mutual interaction with other peoples and social activities face to face directly. Gadgets make children tend to spend time by playing games and having their own world rather than having real communication with family or friends. It causes anti-social problems. [1] states that because of the solitary nature of most computer activities, concerns have been raised that children might form "electronic friendships" with the machine, instead of friendships with their peers, hindering the development of interpersonal skills.

\section{c. Lack of Interest in Studying}

Excessive use of gadgets because children become lazy to study and they also lose their interest to study. They prefer to choose playing gadgets to studying. They would rather rely on gadgets and internet, instead of their books and the input from their teachers, because of gadgets addiction. Gadgets also make them lose their concentration due to lack of sleep and tired, because some stay up late to use gadgets.

\section{d. Negative Impact on Character}

According to [2] gadgets can bring negative impact on character. This is one of the biggest problems in this growing world of technology. Children use internet to see adult content rather to search for educational websites. This practice leads bad impact on their character, they forgot their moral values. The negative contents are easily to find on internet, because there are so many websites provide negative contents that can be accessed by 
children. Without parental guidance, children will think that it's a proper content based on their ages.

\subsection{The Efforts to Prevent the Gadget Addiction in Children}

Parents have essential role in helping children to prevent the gadget addiction. Some children get addicted to technology since they start living in environment where their family or even parents serve them with tons of gadgets. They feel better by playing gadgets all day long instead of doing other activities outside. Parents should know and understand that the importance of children's healthy development involves social interaction, creative imaginative play and an engagement with the real, natural world. Parents must help children todivert children's attention from gadgets and it can be done in the following ways:

\section{a. Being a Role Model}

Children is a great imitator. They imitate adults' behavior. They see and observe them, then imitate and apply it. If they see their parents read a book, they are more likely to read and if they see their parents play gadgets, they will ask them for it. If parents did something good, they will be good and if parents give bad examples, they will do the same things. As a parent, never play the gadgets in front of children, in order to avoid them from the gadget addiction.

\section{b. Be Involved in Children's Lives}

Parents can take wise decision by spending more time with children. Children who are found to be lonely are more likely to look for a sort of companionship in gadgets. For many parents, it is just easier to turn on the gadgets rather than to be involved in their children's lives. Good parents should be a observer, listener and teacher for successful parenting.

\section{c. Encourage Positive Activities}

Parents have to provide positive activities for children, such as playing football or chess, drawing, coloring, reading books, playing piano and so on. Therefore, parents should provide the necessary resources, like books to read, board games, art supplies, sport equipment, so that children can have many things to do.

\section{d. Ask Children to Play with Friends}

One of the reasons why a child playing a gadget because there is no fun activity to play with friends. So that, parents need to ask children to play with their peers, by inviting friends to play at home or asking them to visit friend's house at school. With a lot of friends, children will have a new activity and can forget the gadget.

\section{Result and Discussion}

There are many ways to avoid children from gadgets' addiction, but the best way is by helping children to find their talents and interests in order to make them be more creative. Every child is special in their own way. Each has own talent and interest who make them special. Unfortunately, some children and even adults do not know their own talent, because some people never try to find it or some knows it, but has no desire to develop it. As Wolfgang Riebe's proverb, "Everyone is gifted, but most people never open their package". 
There seems to be a difference in talent and interest in psychology that can be a guideline for knowing specifications that are typical of talent or interest. Both are often considered the same or difficult to distinguish. Some say that real talent can be nurtured, while interest will depend heavily on talent. The talent in general is also identical to the abilities that a person has since he/she was born. A person may have certain abilities that are inherited from their parents. Meanwhile, interest is the desire of someone to learn something that is his favorite or favorite. Interest and talent when combined will be a very good thing in supporting one's goals and ideals.

\section{a. Definition of Talent}

Every child has own talent that should be developed since early age to make them to be more optimal and creative in the future. Euis states in [3] elaborates talent as innate ability, as a potential that still needs to be developed and trained in order to materialize. In this case talent requires training and education so that an action can be done in the future. Achievement is a manifestation of talent and ability. A very prominent achievement in one field reflects superior talent in the field. In simple terms, it can be concluded that talent is a potential innate ability which still needs to be trained and developed, so that it can become a capable ability and skill.

[3] says, "Some experts tend to distinguish talent based on general talent and special talent. Gifted is interpreted as intellectual talent (both public and special) and talent as special talents, for example in the art of music or fine arts. These talents, both potential and realized ones, include: (a) General intellectual ability, (b) Special academic ability, (c) Ability to think creatively-productive, (d) Ability in one field of art, (e) Psychomotor /kinesthetic ability and (f) Psychosocial ability or leadership talent”.

\section{b. Definition of Interest}

[4] explains that interest is an attitude that goes on continuously that is able to make a person's attention pattern so that he becomes selective about the object of interest. In simple, interest means a high tendency and passion or a great desire for something. Interest can be related to the power of movement and the motivation of someone to tend to feel attracted to people, things, activities or can be an effective experience stimulated by their own activities. Interest can be a cause of participation in an activity. Interest is very personal, even though it is very personal, interest is influenced by the environment. Everyone must develop their interests.

According to Slameto in [3], the characteristics of interest that exist in each individual are as follow: (1) Interest is not taken from birth, but it is formed and learned later, (2) Interest can be expressed through a question that shows that students prefer something more than anything else, (3) Interest can be manifested through participation in an activity, (4) Interest in terms of motivation and feeling. Children who have an interest in an object will tend to give greater attention to the object.

\section{c. Ways to Discover Children's Talents and Interests}

Everyone certainly has the ability which comes from within themselves which can be derived from parents or indeed a natural talent that someone has. Of course, as a parent, it is important to know the talent of children from an early age so that you can direct the best possible talents, so that they are maximized along with the development and growth of the child. Here are several ways to find out child's talent from an early age that can be done by parents. 1) Paying Attention to the Children's Habits and Passions. The first way to find out 
what child has is to pay attention to children's habits and passions. Usually things that become habits and favorites can be a talent that your child has. So, try to pay attention to all the children's activities, maybe one of them is a talent or potential that is strong enough to be explored further. Starting from habits, preferences, hobbies, things that are often done, interests and everything parents need to pay attention to. 2) Allowing Children to Explore Abilities. Parents should let children to try a variety of positive things, in this way will help the children find the hidden talents in them and it also can avoid children from play gadgets. As a parent, do not occasionally limit children's activities. Preventing children from exploring their abilities will make themunable to maximize to find hidden talents in themselves. Parents have to do is to supervise all the children's activities, if later there are things that a child likes, parents can direct them further. 3) Entering Children into Several Competitions. Another good step that parents can do is to include children in several competitions, but remember all these things must be in accordance with the children's agreement. Parents can observe the talents and interests of the children from the competition that children follow. The results of the race that has the highest achievement can be an indication if the child's ability is more dominant in that. When entering children in the competition, parents should not give too high targets that will only make children become depressed. Children will not perform maximally, because they only will be burdened with the target that parents have set. The wisest thing is to accompany children when they take part in the competition by giving a lot of positive reinforcement that can strengthen children.

[5] says "The success of early childhood education will depend on whether it can connect the learning environments of home and school. It should be built on the interaction and communication between children, teachers and parents". So that means the effort of parents and teacher are needed to help children in developing talents and interests as a way to avoid the gadget overuse by children.

\section{Conclusion}

Nowadays the gadgets addiction become a serious problem. It needs to be solved as soon as possible in order to avoid further negative effect in the future. Parents have important role to help children to divert children's attention from gadgets and direct them to do more positive activities. The most positive way is by helping children to discover and gain their talents and interest. Many cases where parents can misunderstand the talents that children have so that they ask the child to do an activity without communicating first with the child. This is a matter that must be avoided because it can make children even have difficulty finding the talent they have. For this reason, parents should give children the freedom to be able to choose, play and do their own things. As long as it is still reasonable and has a positive impact, then parent have to support it. Do not forbid children to do something that can make children's talents develop. But if the activity has a negative impact on child, then parents can provide a good explanation and understanding so as not to continue this.

Parents can also find out the talents owned by children through consultation with the teacher at school, especially with class teachers. This is because the class teacher has the task of educating and teaching children every day at school. Moreover, as much as a child's time is spent in a school environment, so most teachers certainly know and understand the hidden talents of children. In addition, the class teacher also understands what are the weaknesses and strengths to the talents of child. Therefore, parents can try to consult with the teacher about the 
talents owned by the child by discussing them. Once children have found their talents and interests, they will be busier and happier to develop their talents and interests rather than play gadgets all day long. This is also be an effective way of parents to prevent gadget overuse by children and it can be a solution to avoid children from negative impact of gadgets.

\section{References}

[1] K. Subrahmanyam, "The Impact of Computer Use on Children's and Adolescents' Development," Appl. Dev. Psychol. J., vol. 22, pp. 7-30, 2011.

[2] M. Sundus, "The Impact of using Gadgets on Children," J. Depress. Anxiety, vol. 7, no. 1, 2018.

[3] M. Amin, Pengembangan bakat dan minat siswa SMK. Jakarta: Direktorat Pembinaan SMK Ditjen Dikdasmen Kemdikbud, 2016.

[4] J. P. Chaplin, Kamus Lengkap Psikologi. Jakarta: Grafindo Persada, 1995.

[5] Y. Y. K. Keong, Nurturing Creative Children. 2004. 